\author{
Crossing the Border: International Journal of Interdisciplinary Studies \\ Volume 4; Number 1; 15 April 2016 \\ ISSN 2350-8752 (Print); ISSN 2350-8922 (Online)
}

\title{
TRANSFORM SPATIAL: MAKING THE CASE FOR SPATIAL THINKING IN HIGHER EDUCATION
}

Alex Lowry (USA)

\begin{abstract}
This white paper argues in favor of an interdisciplinary approach to curriculum design that places greater emphasis on spatial thinking in order to prepare students in higher education for life and careers in the 21st century. While part one of the paper outlines and supports various claims regarding spatial thinking, the second part of the paper proposes an intervention, and introduces the transformed curriculum of a compulsory first-year composition course that emphasizes spatial thinking and experiential learning.
\end{abstract}

KEYWORDS: Spatial abilities; intelligence; dual coding theory; curriculum; GIS; projectbased learning

\section{INTRODUCTION}

Spatial thinking is often overlooked and underappreciated, particularly in the field of education in the United States. Goodchild and Janelle (2010) question the efficacy of ignoring the spatial:

Perhaps these abilities are instinctive, or acquired at such an early age that they require no attention from our educational system. Or, are society and its approach to education failing to nurture a fundamental element of human intelligence? (p. 3) The goal of this paper is to reassert the primacy and importance of spatial thinking, and to encourage more emphasis thereupon at the level of the first-year composition course.

The researcher's claims are as follows: 1) Spatial processing is inherently intermodal and distributed (redundantly mapped to many parts of the brain); 2) Spatial thinking has a vital role in 21st century skills; 3) Spatial thinking \& learning is interdisciplinary; 4) Engaging in spatial thinking \& learning (practice) can improve domain-general spatial abilities; and 5) Greater emphasis on spatial skills and spatial thinking leads to more equitable outcomes. Therefore, providing undergraduates with pedagogy informed by spatial thinking, with maps, images, models and connections made to the world around them, will be efficacious for providing them with 21st century skills, which emphasize flexibility, creativity, deep learning and systems thinking, and will likely lead to better, more equitable, learning outcomes. These claims will be further described, elaborated upon, and supported in the body of the literature review.

\section{METHODOLOGY}

This paper is part literature review and part research proposal. The first section is descriptive and will review the literature related to spatial thinking as it pertains to the stated claims above. As such, the paper is deductive in approach. The second part of the paper is prescriptive, consisting of a research proposal centered around a transformed first-year composition course in order to measure the efficacy of spatial pedagogy: in the 


\section{Crossing the Border: International Journal of Interdisciplinary Studies}

short term, the impact it has on domain general spatial abilities, attitudes towards ICT, and growth mindset; longitudinally, the impact, if any, it has on college success, choice of major, and life after college. This research proposal has been produced with the intent that it be adopted by and coordinated among any interested third parties. The goal is to provide justification and a model for action - for connecting theory with practice, and for transformation of the first-year writing curriculum and ideology.

\section{DEFINITIONS AND FRAMEWORKS}

For the sake of clarity, this paper will define spatial terms. Subsequent to that and to resolve any confusion, we will present a relevant framework for defining and conceptualizing spatial abilities. The framework for 21 st century learning outcomes will be presented later in the paper where it is relevant.

The meaning of spatial intelligence is fluid, possibly because it is difficult to define something that is both basic and nonlinguistic in nature. The notion of spatial intelligence existed long before Gardner's Frames of Mind (1985). For instance, three out of four of Aristotle's laws of association are spatial in nature (Boeree, 2000). Much later, Piaget defined spatial intelligence in terms of development, positing that human beings move from having "topographic" spatial intelligence that is primarily egocentric, through a projected phase, to a final phase around age 8 or 9 where more dynamic and complex conceptions of space are possible (Piaget \& Inhelder, 1948). Later on, Eliot and Smith (1983) described spatial reasoning as the "perception and retention of visual forms and the mental manipulation and reconstruction of visual shapes," while Linn and Peterson defined spatial ability as "representing, generating and recalling symbolic, nonlinguistic information" (1985).

Although sometimes its meaning is confused and bound up with the other phrases, generally people seem to agree on spatial abilities (also referred to as spatial skills), which are narrow in definition. Psychologists usually put these into two categories, spatial visualization and spatial orientation. Spatial visualization describes the ability to visualize and mentally transform objects by twisting, rotating, or moving them, etc. while spatial orientation has to do with one's sense of direction within one's environment (Bednarz \& Lee, 2011). Confusing matters, researchers disagree on where spatial relations belong. According to Golledge and Stimson's definition, spatial relations include the "abilities to recognize spatial distributions and spatial patterns, to connect locations, to associate and correlate spatially distributed phenomena, to comprehend and use spatial hierarchies, to regionalize, to orientate to real-world frames of reference, to imagine maps from verbal descriptions, to sketch maps, to compare maps, and to overlay and dissolve maps" (1997). Many psychologists believe that spatial relations belong as a contested third category of spatial abilities (Gilmartin \& Patton, 1984; Golledge \& Stimson, 1997; Lohman, 1979; Montello, Lovelace, Golledge, \& Self, 1999). Others, such as Golledge and Stimson (1997), are prone to couch spatial relations with spatial thinking.

Spatial thinking is less decomposed than spatial abilities. The National Research Council treated spatial thinking as consisting of three parts: (1) concepts of space, (2) methods used to represent space, and (3) the processes of spatial reasoning (2006). Golledge and Stimson(1997), on the other hand, are less domain general, and describe spatial thinking as understanding spatial relations. Thus, there seems to be some disagreement as to whether spatial relations belongs under spatial abilities, which would imply that it's something epistemic and measurable via psychometric tests, or whether it is part of the more broadly defined spatial thinking. Spatial abilities are probably best viewed as a fundamental part of spatial thinking (thoughts or processes, often domain-specific, related to spatial) and spatial intelligence (the aggregation of all spatial abilities and processes). 
The Spatial Intelligence and Learning Center (SILC) expands on the typical dichotomy of spatial abilities, which they refer to as spatial skills because abilities "tends to connote a more fixed entity than the evidence justifies" (N. Newcombe, Epstein, \& Shipley, 2015):

1. Intrinsic-Static. Coding the spatial features of objects, including their size and the arrangement of their parts - i.e., their configuration (e.g., to identify objects as members of categories)

2. Intrinsic-Dynamic. Transforming the spatial codings of objects, including rotation, cross-sectioning, folding, plastic deformations (e.g., to imagine some future state of affairs)

3. Extrinsic-Static. Coding the spatial location of objects relative to other objects or to a reference frame (e.g., to represent configurations of objects that constitute the environment and to combine continuous and categorical information)

4. Extrinsic-Dynamic. Transforming the inter-relations of objects as one or more of them moves, including the viewer (e.g., to maintain a stable representation of the world during navigation and to enable perspective taking).(N. Newcombe et al., 2015)

In this paper, we accept the above framework put forth by SILC and the metrics prescribed for measuring spatial skills that we will use to operationalize our hypothesis. Furthermore, spatial skills and abilities are measurable and domain-general, but form the basis for domain-specific spatial thinking and problem solving. Lastly, spatial processing may be used interchangeably with spatial thinking.

\section{LITERATURE REVIEW}

A review of the literature on spatial thinking and abilities will explore and test the veracity of the claims put forth.

\section{Spatial processing is inherently intermodal and distributed}

This claim is put forth to support the notion that spatial thinking and learning is vital in education, as spatial processing provides the foundation for human cognition. In the context of our claim, modal describes the senses, and spatial processing is multimodal at the first order, processing information from the senses. Modal can also describe ways of thinking and cognition, however. For instance, Gardner's theory of multiple intelligences (1985) posited that there were seven modes of thinking, or seven intelligences. Seen this way, our claim that spatial intelligence is intermodal implies that spatial intelligence is not a discrete way of thinking at all but one with cross-modal translational characteristics, perhaps similar in some ways to the supervening "general intelligence" concept in the CattellHorn-Carroll (CHC) theory of intelligence.

Despite using the terms "spatial processing" and "spatial intelligence," our claim is a refutation of multiple intelligences, which equates spatial with visual and views the intelligences as discrete and observable phenomena (Gardner, 1985). The claim is not satisfied by the theory of multiple intelligences. Other explanations of human cognition, such as dualcoding theory (Paivio, 1983), Kahneman's two-systems theory (2011), and hybrid neural network \& symbolic AI cognitive models (Garcez, Broda, \& Gabbay, 2012; Sun \& Alexandre, 2013), provide more relevant models. This section focuses on learning and cognition at the individual level of analysis - the brain.

Spatial processing often gets conflated with the visual sense, which describes only one mode. Gardner, for instance, labeled one of his multiple intelligences "visual-spatial" (1985). There is no doubt visual and spatial are closely related, but they exist at different levels in the cognition process and their relationship is not one-to-one. The relationship between the senses and spatial intelligence is many-to-one. Furthermore, Gardner's multiple 


\section{Crossing the Border: International Journal of Interdisciplinary Studies}

intelligence theory seems to rest on the assumption that intelligences are discrete and modular, when it's pretty clear that there is some overlap between the intelligences - that is, they are not discrete - notably with regards to the spatial. Take musical intelligence, for example. Don't we learn to play the piano on keys which are divided between black and white ones, and whose spatial order repeats itself? Don't we learn to read musical composition and tablature, which exists spatially, and to convert this information through kinesthetic action into music, which takes place over time? And when we learn to play an instrument such as the guitar, do we not learn the chord shapes which we process spatially and try to engrain into our kinesthetic muscle memory through practice? And when we listen to music, particularly music played through headphones or stereo speakers, and close our eyes, can we not visualize the different instrument parts as though they reside at different locations of an imaginary stage? Which intelligence or processing is responsible for such a spatial notion?

Thus the simple statement (one half of the first claim) that spatial intelligence is intermodal, seems to have two prongs: 1) the relationship between the senses and spatial processing is many-to-one (it is multimodal, not just "visual") and 2) spatial processing is a first-order process and has a role in cross-modal articulation or translation between other cognitive activities and domains. In particular, with respect to their connections with spatial processing, we will focus on the domains of verbal and logical maths, which are alternatively referred to in the literature as intelligences (c.f. Gardner) and as factors of $g$ (c.f. Cattell, Horn, \& Carroll).

\section{Spatial and verbal connections}

The connection of spatial processing to verbal processing is both well documented and intriguing. Spatial thinking has been described as the perfect complement to verbal thinking (Carroll 1993; Bornstein 2009). The dual coding theory attempts to explain human cognition by asserting that we use two functionally independent but interrelated modal-specific multimodal representational systems: verbal and non-verbal (Paivio, 1983), and these are fundamental, first-order systems. Put simply, language and mental images (or sounds, smells, etc.) are inextricably tied to one another. Paivio asserted that the relationship between the two systems is many-to-many (2010), which implies that when we see a

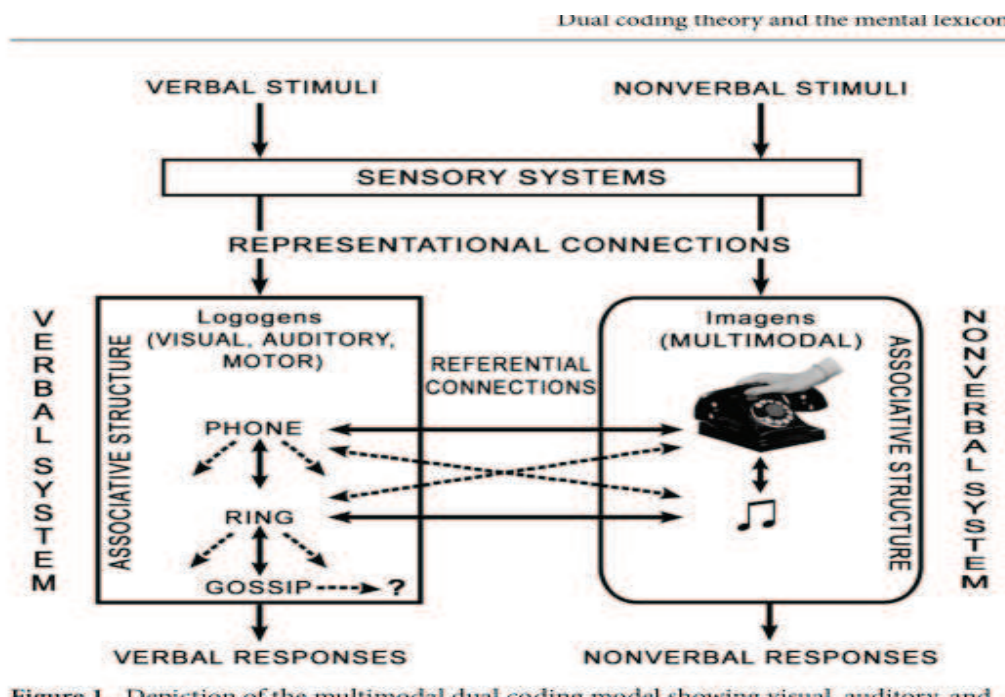

Figure 1. Depiction of the multimodal dual coding model showing visual, auditory, and haptic logogens and imagens corresponding to the names and sensorimotor properties of the object telephone. 
word or an image, we think of other words or images related to that stimuli. Sadoski and Paivio (2001) point out that both systems influence one another organically, both in language reception and recovering it for production.

Dual coding theory (DCT) supports our claim that the nonverbal (spatial) is multimodal, and that it is of first-order, fundamental importance to cognition. DCT also asserts that verbal and nonverbal are interrelated, and map onto one another in complex ways.

Support for the second portion of the claim, that spatial processing performs an important role in cross-modal translation, can be found embedded in the literature of cognitive psychologists and, notably, Vygotskian proponents of extended cognition. For example, Clark (2008) asserted that "spatial groupings are used in teaching children the meanings of words, and mentally rehearsed words may be used to control activities of spatial grouping" thus describing the back-and-forth between the two systems. Additionally, a study by Hermer-Vazquez, et. al., (1999) on prelinguistic infants found that language was necessary for subjects to complete a task that required them to combine both geometric (shape, location) and nongeometric (color) cues in order to solve. Prelinguistic children were shown where an object was hidden, and were subsequently disoriented so that they had to combine the clues that had been available to them. They failed to accomplish the task, whereas older children had no trouble since, the investigators concluded, they were able to combine the geometric and nongeometric cues using verbal processing, as they would in a sentence such as "behind the long green wall". This study suggests that it is the verbal system that engenders a unique internal representational medium for the cross-modal integration of information (Carruthers, 2002; A. Clark, 2008). DCT does not take such a modular perspective on cognition, however, implying integration of the two systems. In other words, you cannot divorce the spatial/nonverbal from the verbal sentence "behind the green wall." There is a lot of literature to support the notion of integration put forth by DCT. For instance, Damasio (1994), a famous neuroscientist, described language as being always a translation of something else, "a conversion from non-linguistic images which stand for entities, events, relationships and inferences" (p. 107). Stevick asserts that "an exchange of words is communicative only when it causes some modification of images in the hearer's mind" (1986, p. 16). Vygotsky's explorations on tool use and the development of speech in young children touches upon the connection between speech and the spatial situation of the child: from the moment the child begins to master the situation with the help of speech, a radically new organization of behavior appears, as well as new relations with the environment (1978).

Moreover, Vygostky noted that during children's pre-abstraction phase, speech accompanies action. Symbols are not yet internalized and therefore, he noted, "young children name their drawings only after they have completed them" (1978, p. 27). After children have developed the ability to abstract and internalize symbols, speech comes to precede action and function as a sort of "aid to a plan that has been conceived but not yet realized in behavior" (Vygotsky, 1978). At this point, children decide in advance what they will draw. My interpretation of this finding is that during children's early stages of development, the pre-abstraction phase, spatial and language processing are virtually indistinguishable from each other - at least, from the perspective of the child. This would explain why the language acquired during this phase is learned so profoundly and permanently, and why the first books we read are picture books. From an evolutionary perspective, the first symbols we internalized were images. Vygotsky argued that all knowledge started as visible social interaction that was "gradually internalized by the learner to form thought" (Sawyer, 2014, p. 10). After all, Lascaux cave features paintings, not scripts, and there is a compelling theory that language developed from gestures (Arbib, Liebal, \& Pika, 2008). The primacy of 


\section{Crossing the Border: International Journal of Interdisciplinary Studies}

the image is reflected in how we learn, particularly at early stages of development. A recent study (Hutton, Horowitz-Kraus, Mendelsohn, DeWitt, \& Holland, 2015) concluded that more home reading exposure in preschool aged children resulted in greater activation of brain areas associated with mental imagery and narrative comprehension. Authors of the study recommended exposure to storybooks from birth, as a result of these findings.

\section{Spatial and logical-maths connections}

The spatial is strongly connected with mathematical thinking. For instance, math is frequently used to describe objects in 1D (line), 2D (polygon), and 3D (3D object) space. Geometry, Trigonometry, and Calculus were developed as approaches to explain spatial phenomena -mathematics developed out of spatial needs. When we are young, not just in our pre-abstraction phase but afterwards as well, we have trouble learning mathematical concepts without objects to anchor the principles to the real world. Why is that?

What is happening in your mind when you add two to twenty-five? This is debatable, though we can say with some certainty that you just translated a sentence from English into something else (A. Clark, 2008). Dehaene describes this mathematically productive activity as something made possible only by the combination of three cognitively distinct abilities, the first two of which are biologically basic and spatial in nature; the last is verbal.

1. The ability to distinguish small quantities: e.g. one-ness, two-ness, three-ness, morethan-that-ness.

2. The ability to approximate concerning magnitudes or degrees of greatness, such as great vs. tiny, e.g., arrays of 64 versus 8 erasers.

3. The learned capacity to use number words to represent distinct larger quantities. (S Dehaene, 1997; Stanislas Dehaene, Spelke, Pinel, Stanescu, \& Tsivkin, 1999)

In other words, the actual mathematical thought depends on the combination of these resources. Another way of describing this would be to say quite simply that math, even very basic math, requires a combination of spatial and verbal processing. In support of his conclusion, Dahaene, et. al. examined lesion studies where patients with severe left hemisphere damage could not determine whether $2+2=3$ or 4 , but had no problem choosing 3 or 4 over 9 , which indicated that the approximation system had been spared. Dahaene went on to advocate early linkages of the verbal with nonverbal sense of quantities: for a whole year children realize that the number " 3 " is a number without knowing the precise value it refers to (1997, p. 107). For instance, a simple number line, which is a spatial tool, could help children connect numbers with precise quantities.

If what Dahaene, et. al., are suggesting is true, then mathematical processing is a second-order operation carried out by first-order substrate of thought - verbal and nonverbal. If this is true, then it would be reasonable to assume that spatial skills would be a strong predictor of math ability. In fact, some research supports this notion (Rohde \& Thompson, 2007), but Friedman (1995) in a meta-analysis of the literature determined that verbal ability is a stronger predictor of mathematical achievement than was spatial ability. The findings, however, were mixed and the research suffers from being more correlational than experimental in nature. Hannifan, et. al., compared the performances between two groups on a mathematical principles post-test - the first group received a spatial intervention with Sketchpad 3D software, while the control group received only a step-by-step (linear) tutorial. Their performances on the post-test were not significantly different, which the research group reasoned may have been because they made the tutorial "too good" and perhaps the programs were not significantly different (Hannafin, Truxaw, Vermillion, \& Liu, 2008). However, it could be for another reason, and could be illustrative of a problem with much of the experimental literature on the connection between math and spatial abili- 
ties: if Dahaene, et. al. are correct and mathematical processing does depend on both verbal and nonverbal processes, then privileging one over the other in experimental research may not be the correct approach. That said, more research should be done to better establish the connection between spatial skills and math abilities.

In contrast, there seems to be a lack of controversy regarding the efficacy of using manipulatives in geometry instruction (Clements \& Battista, 1992; Jones, 2010) and several researches have concluded that the use of manipulatives can lead to improvement of spatial skills - specifically, that using manipulatives contributed to improvement in spatial visualization (Arıcı \& Aslan-Tutak, 2015; Bayrak, 2008; Çakmak, 2009).

\section{Neuroscience findings}

We turn to neuroscience to support the second part of claim one: that spatial processing is distributed throughout the brain. Gaddis, a historian, posited that pattern recognition, a function of spatial thinking, is the "primary form of human perception" (2002), but recently the question "does the human brain work solely by pattern recognition?" was asked on the knowledge website Quora. Two neuroscientists argued that, basically, it does (Bush, 2015; John, 2015), with one rephrasing the statement to "'activating the appropriate ensemble of neurons in each situation (best fit to current input and memory"' (Bush, 2015) to account for motor skills and abstract thought. Their views are representative of the neuroscience and neural networks AI perspective on human cognition. According to this perspective, pattern recognition can explain everything that happens in the brain at a molecular level.

From neuroscience research, there is more compelling evidence that suggests that spatial thinking is distributed throughout the brain and plays an adaptive role in overcoming cognitive adversity. The brain has certain parts that are dedicated to particular functions. For example, Broca'sarea located in the occipital lobe and Wernicke's area in the temporal lobe are connected with speech. Damage to either of these areas would likely have a significant effect on one's ability to speak. Additionally, in the frontal lobe is an area called the motor cortex, which is largely responsible for monitoring our body's movements. Damage to this part of the brain has a predictable effect on movement and coordination. Our ability to process spatial information, however, is more fundamental and distributed throughout the brain.

Gersmehl and Gersmehl (2007) cited evidence from neuroscience that spatial concepts are mapped to different parts of the brain. Furthermore, spatial processing plays an important role in the phenomenon of neuroplasticity, which describes the brain's ability to adapt or "rewire" itself after cognitive or sensory damage or loss (Chinnery \& Thompson Simon, 2015; Collignon, Voss, Lassonde, \& Lepore, 2009; Voss et al., 2004). Notably, human beings who have lost the ability to see can learn echolocation whereby they map out their surroundings by the sound of a click and its report. This visualization of their surroundings occurs in the same part of the brain that we associate with vision, and cognitive psychologists often refer to this phenomenon as evidence of neuroplasticity. This is why blind people are able to visualize their environment through the use of other senses, such as the aural or tactile senses, and this information is also processed in the "visual" part of the brain, the visual cortex in the occipital lobe.

Experiments on humans using Tactile-Visual Substitution Systems (TVSS) have furthermore shown that these substitute systems performed ably and transparently on tasks that included "face recognition, accurate judgment of speed and direction of a rolling ball with over $95 \%$ accuracy in batting the ball as it rolls over a table edge, and complex inspection assembly tasks" (Bach-y-Rita, Tyler, \& Kaczmarek, 2003, p. 287), which is further 


\section{Crossing the Border: International Journal of Interdisciplinary Studies}

evidence of the role of spatial processing in plasticity.

Based on these assertions, we can conclude that spatial thinking has an important role in deep learning and multimodal literacies, and will prove vital in preparing our students for the roles they will have in the 21st century.

\section{Impact on 21 st century skills}

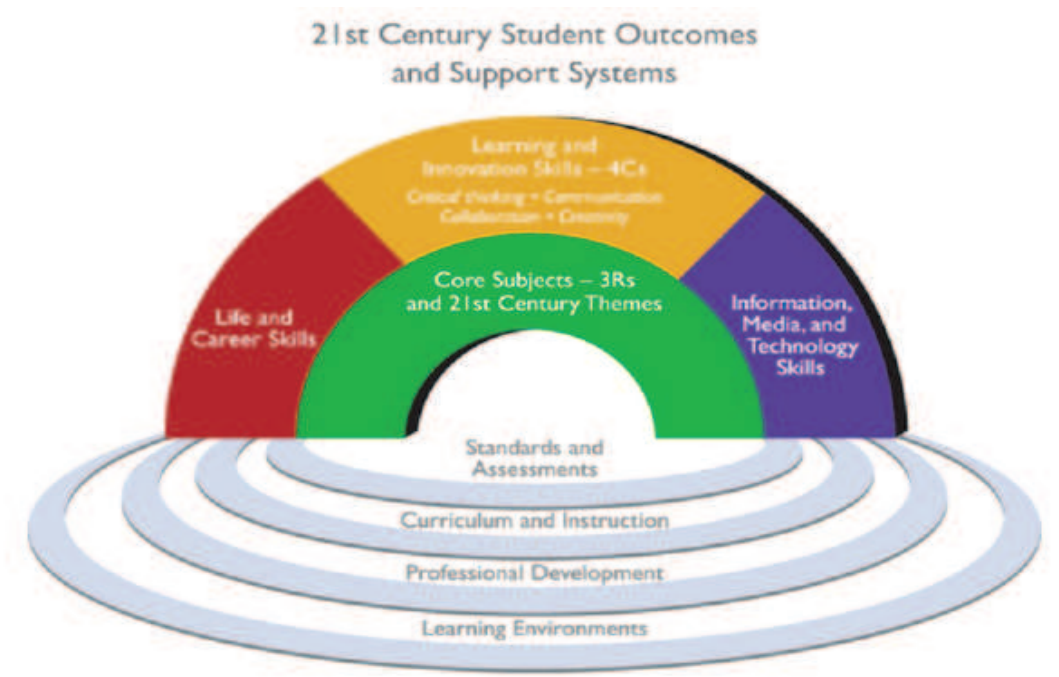

Figure 1.2. The 21st century student outcomes from the Partnership for 21st century skills (P21, 2011).

Clearly the spatial plays an evolutionary and adaptive role on a molecular level in the phenomenon of plasticity. Does this flexible and adaptive quality, which is seen at the molecular level, convey to the level of the individual? Absolutely - the blind person can now "see" and navigate their surroundings no matter what part of the brain is responsible. Newcombe and Frick (2010) describe the evolutionary importance of spatial processing, that this gave us the ability to make and use tools. Bethune (2011) defines spatial intelligence as the ability to grasp a changing whole and anticipate its next stage, and the ability to make quick decisions - to size up all the relationships in a fast-changing array and understand them. How quickly and accurately we perceive and interpret the world, and which direction the objects within it are likely heading, clearly impacts our ability to react and make adjustments.

More research suggests that spatial thinking has an important role in promoting flexibility and adaptability, which taken together is an important part of the "life and career skills" learning outcome in the 21st century skills. Researches in the domains of mechanics and chemistry found that visual-spatial strategies are default "domain-general problem solving heuristics" (Hegarty, Crookes, Dara-Abrams, \& Shipley, 2010) employed by both novices and experts in novel situations, whereas rule-based analytic strategies are used by experts in routine problem solving (Schwartz \& Black, 1996; Stieff, 2007). This highlights the adaptability of spatial intelligence and how domain-general spatial skills can transfer to different domains, but there is creativity in adaptability. No doubt, there is a reason the secular notion of creativity emerges only after Darwin and the adaptability of species hypothesis (Nelson 2015): "Darwin showed that nature could be creative" (Sawyer, 2015). Creativity springs forth from not knowing how to do something, though this is a necessary condition, not a sufficient one. Cropley (2006), for instance, warns that the preexisting knowledge of an expert might actually hinder creativity, because it leads to convergent 
thinking and the production of "tried and trusted, correct answers" (p. 402). The opposite is true in the creative domains of art and design, where expertise is mainly associated with divergent thinking, and rule-based thinking is at the bottom of the hierarchy of knowledge; rule-based strategies are generally what novices use, although in any given activity an artist might employ all four forms of thinking: rule-based, convention-based, situation-based, and strategy-based (Lawson \& Dorst, 2013). From the above researches, we can confidently associate spatial thinking with creativity and innovation, and critical thinking \& problem solving from the 21st century skills. The following creative breakthroughs are examples of how spatial thinking and visualization changed the world (See Fig. 1.3 below).

\begin{tabular}{|c|c|c|c|}
\hline $\begin{array}{l}\text { Scien- } \\
\text { tist }\end{array}$ & $\begin{array}{l}\text { Break- } \\
\text { through / } \\
\text { Invention }\end{array}$ & $\begin{array}{c}\text { Crude Visualiza- } \\
\text { tion }\end{array}$ & Story \\
\hline Newton & $\begin{array}{l}\text { Law gov- } \\
\text { erning fall- } \\
\text { ing bodies/ } \\
\text { calculus }\end{array}$ & tase & $\begin{array}{l}\text { Newton reportedly saw an apple fall, and the } \\
\text { moon was nearby. He began wondering whether } \\
\text { the moon also fell towards the Earth. He devised } \\
\text { Calculus in order to explain this phenomenon. }\end{array}$ \\
\hline Tesla & $\begin{array}{l}\text { dynamo } \\
\text { electric } \\
\text { machine }\end{array}$ & & $\begin{array}{l}\text { Tesla claimed that the idea for the dynamo came to } \\
\text { him during a daydream. His history with visu- } \\
\text { alization is much more extensive and elaborate, } \\
\text { however. } \\
\text { "My method is different. I do not rush into actual } \\
\text { work. When I get a new idea, I start at once build- } \\
\text { ing it up in my imagination, and make improve- } \\
\text { ments and operate the device in my mind. When } \\
\text { I have gone so far as to embody everything in } \\
\text { my invention, every possible improvement I can } \\
\text { think of, and when I see no fault anywhere, I put } \\
\text { into concrete form the final product of my brain." } \\
\text {-Nikola Tesla }\end{array}$ \\
\hline Einstein & $\begin{array}{l}\text { Theory of } \\
\text { Relativity }\end{array}$ & & $\begin{array}{l}\text { Einstein came up with the theory of relativity, he } \\
\text { said, by visualizing himself riding atop a beam of } \\
\text { light, looking backwards. He imagined what he } \\
\text { might see. }\end{array}$ \\
\hline $\begin{array}{l}\text { Watson } \\
\text { \& Crick }\end{array}$ & $\begin{array}{l}\text { DNA } \\
\text { structure } \\
\text { - double } \\
\text { helix }\end{array}$ & & $\begin{array}{l}\text { Watson \& Crick's "discovery" of DNA's double } \\
\text { helix shape came when they successfully trans- } \\
\text { posed a 3-D model from Rosalind Franklin's flat } \\
\text { images of the molecule. }\end{array}$ \\
\hline $\begin{array}{l}\text { Michael } \\
\text { Faraday }\end{array}$ & $\begin{array}{l}\text { lines of } \\
\text { force }\end{array}$ & & $\begin{array}{l}\text { Faraday postulated the relationship between } \\
\text { magnetic and electrical force by seeing what was } \\
\text { not there. He imagined the presence of energy at } \\
\text { the ends of a magnet in the form of curved lines } \\
\text { by witnessing how materials such as iron filings } \\
\text { responded to the magnets. }\end{array}$ \\
\hline
\end{tabular}

Figure 1.3. A shortlist of scientific breakthroughs for which spatial thinking was a catalyst. (Images courtesy of Google image.)

These are revolutionary discoveries that irrevocably altered the respective field and changed the world. You cannot say that you're a proponent of creativity, 21st century skills, and STEM disciplines without acknowledging the important role of spatial thinking; it has 


\section{Crossing the Border: International Journal of Interdisciplinary Studies}

regularly performed an ordinary role in extraordinary breakthroughs.

Furthermore, geographic representations such as a GIS can be used as interdisciplinary mediating tools that engage learners in several areas of the 21st century skills. GIS can be used to engage in the core subjects listed in the P21 framework - all of them, but the most poignant examples include global literacy, civic literacy and environmental literacy. In the "Life and Career Skills" section, we have already described at length the connection to flexibility and adaptability, but usage of geographic representations and a spatial-oriented curriculum can also encourage engagement with the local environment, and engagement with other cultures (again using maps as mediating tools), which address the social and cross-cultural skills outcome in addition to the literacies already mentioned. Lastly, getting students to engage with technology in the form of tools such as a GIS should increase their new media literacy, which is described in the "Information, Media and Technology Skills" section of the 21st century skills framework. These skills include information literacy, media literacy, and ICT literacy. We aim to test this assertion through our research.

The first-year composition course is an opportunity to provide students with these skills that they will need in the 21st century knowledge economy by incorporating spatial thinking and geographic representations such as GIS into the course design and pedagogy.

\section{SPATIAL THINKING AND LEARNING AS INTERDISCIPLINARY}

Perhaps because spatial processing is fundamental, connected with the verbal in profound and inextricable ways, and distributed throughout the brain, spatial thinking and learning is inherently interdisciplinary - we can learn many subjects more effectively through this medium. Thus the NRC pushed for the use of GIS in "a variety of educational settings" (Council, 2006).

Spatial thinking and learning helps in domains and subjects that may not seem relevant on the surface (N. S. Newcombe \& Frick, 2010), such as history, economics, and literature. Dewey advocated a kind of fusion between history and geography, that this amalgam would then be "taught with reference to its bearing on human life" (Dewey, 1990, p. 319). Furthermore, geography, a word that means "earth writing", points to the subject's interdisciplinary origins precariously positioned between the sciences and humanities (Travis, 2015a). In economics, the spatial has never been more relevant, with Krugman winning the Nobel Prize in 2008 for using geographic analysis of economic data, and others already using GIS as a pedagogical medium for teaching economic concepts (Peterson, 2000). In literature, the spatial (GIS, in particular) is perhaps less appreciated and understood, with many scholars lamenting the approach to complexity as either "elementary or primitive ... at best, or environmental determinism at worst" (Bodenhamer, Corrigan, \& Harris, 2010) although Bakhtin argued that it was a fundamental concept to literature, and posited the idea of the chronotope, a spatio-temporal matrix that shapes all narratives (Morris, 2009). GIS and Web 2.0 applications have explored this connection, and one can see the digital artifacts made by students on websites such as GoogleLitTrips and Timemapper. (See also: Deep Maps (Corrigan, 2015) and Travis's geoliterary work on James Joyce's Ulysses (2015b).

The connection of the spatial to STEM is a lot more obvious, as spatial skills are "critically important" in these disciplines (N. S. Newcombe \& Frick, 2010). The introduction to the Cambridge handbook for the Learning Sciences posits the following conclusions regarding situated learning:

- Professionals use complex representations to communicate with each other during collaboration.

- Scientists and mathematicians work with concrete, visual models, so students should too. (Sawyer, 2014, p. 5) 
TRANSFORM SPATIAL

These points highlight the important role of the spatial in authentic situated practice, particularly in STEM subjects. Furthermore, several studies have already established the correlation between spatial skills and success in a variety of STEM disciplines (Hegarty et al., 2010) such as chemistry (Coleman \& Gotch, 1998), engineering (Peters, Chisholm, \& Laeng, 1995; Sorby, 2001), geology (Orion, Ben-Chaim, \& Kali, 1997), mathematics (Casey, Nuttall, \& Pezaris, 1997), physics (Kozhevnikov, Motes, \& Hegarty, 2007) and medicine (Keehner et al., 2004; Schueneman, Pickleman, Hesslein, \& Freeark, 1984), so spatial thinking is relevant in preparing students for careers in these fields.

Given the permeating relevance of the spatial, it may be surprising that the spatial discipline - namely, geography - is neglected in most secondary school curriculums. In his audit of secondary schools in the USA, Kerski noted that many high school districts only require one-half year of geography (2003). Although geography has been described as a "fertile ground for crossing the traditional boundaries of science, social theory, technology and the humanities" (Sui, 2004), and geographers as both "exporters and importers of knowledge" thus making geography a sturdy bridge crossed by many disciplines (Brunn, 2003) as cited in Bodenhamer, et. al. (2010)), what is true for academia does not always hold true in education. Is it possible that students in higher education arrive spatially unprepared for the rigorous work ahead?

\section{Domain Specific Spatial Thinking can Improve Domain General Spatial Skills}

The intermodal and distributed nature of spatial processing and its pervasive relevance-that virtually everything we do involves some measure of spatial processing - might lead one to conclude that we don't need to nurture or hone spatial skills or emphasize spatial thinking, that we do so merely by interacting with the world around us doing everyday activities such as driving a car, doing the dishes or gardening, and this would seem to be a plausible reason for why spatial thinking and spatial skills have been largely ignored by educational systems in the United States (Goodchild \& Janelle, 2010).

The research, however, shows that exposing students to activities that engage spatial processing and utilize spatial abilities has a direct and positive impact on their spatial abilities. Spatial abilities and spatial skills can be improved by spatial work and practice.

As recently as 2006, the NRC cited uncertainty in this regard. In its report entitled Learning to think spatially, the group of investigators asserted that while plausible, transfer between domain specific spatial tasks and domain general spatial skills had not been demonstrated, and called for more research. Newcombe and Frick (2010) described the inconclusive nature of some of this research in their literature review in support of early education for spatial intelligence. While there was plenty of research to support the distributed nature of spatial intelligence and its role in general intelligence (Bornstein, 2009; Carroll, 1993), other research challenged the applicability of the psychometric approach in describing the intellect (McGrew, 2009). And while spatial intelligence was listed as one of the intelligences in the multiple intelligence theory (Gardner, 1985), there have been many criticisms levied against multiple intelligences as being untestable and not particularly rigorous (c.f. Waterhouse (2006)).

Since 2006, however, there have been several demonstrations of the positive effects of spatial work on domain general spatial skills and abilities (Erkoç, Gecü, \& Erkoç, 2013; Lee \& Bednarz, 2009; Wright, Thompson, Ganis, Newcombe, \& Kosslyn, 2008). This research suggests that transfer is not only possible, but demonstrable and replicable. 


\section{Crossing the Border: International Journal of Interdisciplinary Studies}

\section{More Emphasis upon Spatial Thinking and Spatial Abilities Leads to More Equitable Outcomes}

This claim is superficially questionable - What do spatial abilities have to do with equitable outcomes? The argument goes like this. Women and minorities are underrepresented in the STEM disciplines. Spatial skills correlate to careers in STEM (Hegarty et al., 2010) and spatial skills are often used as a predictor for later success in STEM (Humphreys, Lubinski, \& Yao, 1993; Wai, Lubinski, \&Benbow, 2009). Women and minorities tend to score lower on spatial skills tests (such as mental rotation) than white males do. Studies have shown that spatial work, particularly that which uses GIS as a medium, has an impact on spatial skills across the board on a post-test. For instance, Lee and Bednarz (2009) noted in their study on the affects of Geographic Information Systems on spatial skills that performance disparities between the sexes on mental rotation tasks, long documented as something that males do better than females, disappeared in the post-test. Thus spatial pedagogy seems like a tool we could use as a guide to more equitable outcomes in the classroom.

Higher education has become increasingly diverse over the past fifty years, and the impact of the proposed intervention in places where there are many students for whom English is not their first language would be even greater. Kaufman \& Brooks (1996) point out that "verbally-based educational curricula cannot engage language minority students and other students, and do not capture, accurately or equitably, their diverse strengths" (p. 240). Furthermore, other modes such as visual and tactile "are preferable when teachers engage students in exploration of content areas" as they lead to greater learning outcomes and can also "facilitate the acquisition of verbal modes of communication" (Eylon \& Rosenfeld, 1990). Majoy (1993) wrote that spatial thinking and visualization were some of the "most powerful, effective and necessary tools for teachers" (p. 64).

My conclusion is not that spatial thinking and interdisciplinary GIS will lead to more equitable outcomes. We only need to accept that this outcome is plausible, and acknowledge that more research should be done. Notably, we would like to verify the premise that spatial skills and abilities are not static, that they can be improved with practice. We also would like to monitor what effect, if any, the use of spatial pedagogy has on longitudinal outcomes such as choice of major, retention, and career.

\section{INTERVENTION}

The recommended intervention is best characterized as an augmentation of current compulsory curriculum - specifically, the first-year composition course, although such an intervention may seem unnecessary and even superficially absurd. I would argue that the efficacy of such an endeavor is supported by the preceding literature review and moreover reflects our transforming times: in 2015, the Oxford Dictionaries' word of the year was an emoji (2015), and Columbia University's Teachers College granted its first Pd.D. for a dissertation that consisted entirely of a comic (Mulhere, 2015). These are bellwether developments.

Given the intermodal and interdisciplinary nature of spatial thinking, and the interconnected relationship between verbal and nonverbal processing (J. M. Clark \& Paivio, 1991), spatial thinking and GIS-related activities should augment the content, pedagogy and technology of a first-year composition course in complimentary ways.

\section{Methodology}

Having adopted the SILC framework and definitions for spatial skills, we will conduct a pre- and post-test for spatial skills using the SILC psychometric test created by Newcombe, et. al. We will also conduct a pre- and post-survey that is designed to measure attitudes and 
comfort with regard to ICT and digital literacies. In the long term, we will be able to follow students' performance after the course. This data includes:

- GPA

- major

- length of enrollment (how long it takes them to graduate/whether they graduate)

Other forms of data collection that we are considering include a pre-post survey designed to measure growth vs. fixed mindset, and the collection of periodic timed free writing exercises (4) over the course of the semester to see if the Transform Spatial approach is efficacious in terms of the course's writing objectives, or if more attention needs to be explicitly directed to formal composition goals.

\section{EDUC XXX-001}

Transform Spatial: A First-Year Composition Course

\section{Fall 2016}

Instructor:

Email:

Alex Lowry

Office:

abc@unc.edu

Office Hours:

Peabody XXX

Date Syllabus Revised:

15 February 2016

\section{COURSE DESCRIPTION}

Transform spatial is designed as a composition course for the 21st century. The course will utilize critical spatial pedagogy and spatial thinking in order to deliver first-year composition learning outcomes and 21 st century skills.

\section{COURSE GOALS}

This interdisciplinary 3-credit course is designed to deliver the following learning outcomes:

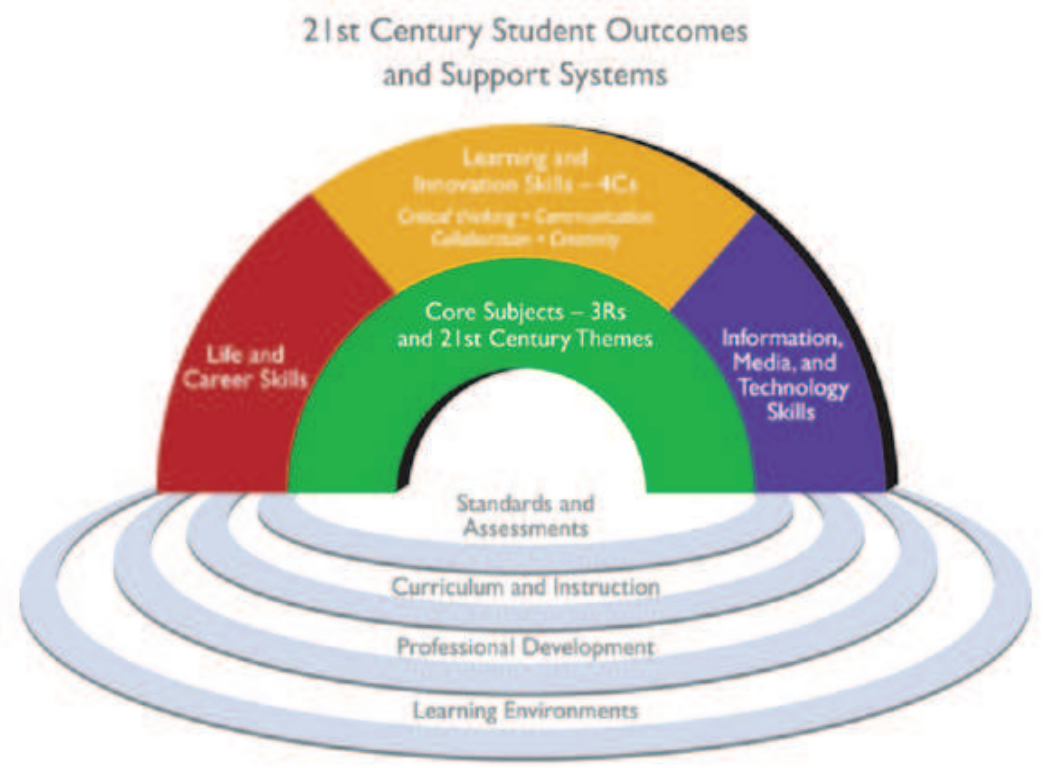

21st Century Skills Framework

www.crossingtheborder.com.np 


\section{Crossing the Border: International Journal of Interdisciplinary Studies}

\section{Core Subjects}

- Increase students' awareness of prescriptive writing forms they will need in college.

- Practice using these forms.

- Get familiar with campus resources dedicated to composition, study skills and self-efficacy.

- Build global awareness through geospatial tools, global texts and cross-cultural subject matter.

- Practice civic literacy through engagement with the local environment and local problem framing.

- Extend environmental literacy through the use of geospatial tools and relevant texts, plus engagement with the local environment.

Life and Career Skills

- Enhance students' abilities to problem frame through engagement with the local environment.

- Increase students' flexibility and adaptability by forcing them to make decisions, take chances and engage in spatial thinking and intermodal translation.

- Foster the qualities of leadership and responsibility, and initiative and self-direction, by engaging students in realistic collaborative projects where they must make decisions and perform in different roles as part of a group.

- Build on social and cross-cultural skills through engagement with the local milieu through class activities, and engagement with other cultures through the use of geospatial tools and global texts.

Learning and Innovation Skills

- Build students' capacity for critical thinking and problem solving.

- Engagement in collaborative writing projects using Google docs.

- Enhance students' abilities to problem frame through engagement with the local environment.

- Expand students' critical thinking and problem solving skills by engaging them in realistic collaborative projects where they must make decisions and perform in different roles as part of a group.

- Encourage creative thinking through the use of generative activities and intermodal translation.

Information, Media and Technology Skills

- Expand students' digital literacy through the use of various apps and computer platforms.
a. blended-style learning environment
b. creation of digital objects
c. usage of web 2.0 tools such as timemapper

\section{CLASS FORMAT}

This is an interactive, interdisciplinary and intermodal course, and you will be required to be present and engaged, whether in the classroom, online, in the library, or elsewhere conducting course work. Often this will require you to take some initiative and responsibility for your actions - I will not always be there to make sure you are present and engaged, but I trust you. You are in charge. If you ever have any questions or doubts as to where you should be, or what you should be doing, reach out to a peer first. If they have the same questions, reach out to me.

Also, I do not ask you to read something for every class. However, when there is a reading assigned for that day, you must come prepared because we will have activities related to the reading and you will not be able to participate fully if you have not prepared. 
TRANSFORM SPATIAL

SCHEDULE \& TOPICS

\begin{tabular}{|c|c|c|}
\hline & Schedule & Texts/Tools \\
\hline $\begin{array}{l}\text { Unit } 1 \text { - My place and } \\
\text { spaces: home } \\
\text { Deliverables: } \\
\text { short presentation } \\
\text { Deliverable: } \\
\text { short presentation }\end{array}$ & $\begin{array}{l}\text { Week } 1 \\
\text { 1. Intro to Course/Icebreakers/ Ed- } \\
\text { modo } \\
\text { 2. Workspace presentation (using } \\
\text { "Explain everything" app or other } \\
\text { screen casting app) } \\
\text { 3. Workspace intervention }\end{array}$ & $\begin{array}{l}\text { Space and Place by } \\
\text { Yi-Fu Tuan } \\
\text { Or In Praise of } \\
\text { Shadows by Junichiro } \\
\text { Tanizaki } \\
\text { Explain everything } \\
\text { or PPT }\end{array}$ \\
\hline $\begin{array}{l}\text { Deliverables: } \\
\text { Timemapper object }\end{array}$ & $\begin{array}{l}\text { Week } 2 \\
\text { 1. Students share re: their text } \\
\text { 2. Comparing different projections/ } \\
\text { navigating a web } 2.0 \text { GIS } \\
\text { 3. Creating your personal timemap } \\
\text { (CPU lab) }\end{array}$ & $\begin{array}{l}\text { students } \rightarrow \text { text }- \text { student } \\
\text { brings in a text related } \\
\text { to home } \\
\text { Web } 2.0- \\
\text { Google Earth Time- } \\
\text { mapper }\end{array}$ \\
\hline $\begin{array}{l}\text { Deliverable: } \\
\text { Essay on "My home" } \\
\text { (Share/submit the pa- } \\
\text { per via Google docs) }\end{array}$ & $\begin{array}{l}\text { Week } 3 \\
\text { 1. Intro to concept mapping the outline } \\
\text { and other visual organizers } \\
\text { 2. Visualization exercise - essay writing } \\
\text { prompt } \\
\text { 3. Writing Resources - online and in- } \\
\text { person }\end{array}$ & $\begin{array}{l}\text { Info gap texts (5) } \\
\text { All the places to love by } \\
\text { Patricia MacLachlan } \\
\text { Purdue OWL } \\
\text { UNC Writing Lab \& } \\
\text { Resources }\end{array}$ \\
\hline $\begin{array}{l}\text { Unit } 2 \text { - My place and } \\
\text { spaces: in the field } \\
\text { Online Quiz: Style and } \\
\text { Citation }\end{array}$ & $\begin{array}{l}\text { Week } 4-\text { Gathering data } \\
\text { 1. Forms of data (qualitative vs. quanti- } \\
\text { tative) and resources } \\
\text { 2. Style and Citation } \\
\text { 3. Library field trip (bib. scavenger } \\
\text { hunt) }\end{array}$ & $\begin{array}{l}\text { Studentsà text students } \\
\text { bring in examples of } \\
\text { data } \\
\text { UNC library (1) } \\
\text { Voyant-tools (1) } \\
\text { Linoit } \\
\text { Google docs (3) }\end{array}$ \\
\hline $\begin{array}{l}\text { Deliverable: } \\
\text { Annotated Bibliogra- } \\
\text { phy (collaborative) } \\
\text { Deliverable: } \\
\text { They say/I say prezis }\end{array}$ & $\begin{array}{l}\text { Week } 5 \text { - Argumentation } \\
\text { 1. They say, I say/Intro to Prezi } \\
\text { 2. Revisiting students' data - creating a } \\
\text { "they say/I say" argument on Prezi } \\
\text { 3. Begin presentations }\end{array}$ & $\begin{array}{l}\text { They say, I say by Graff } \\
\text { \& Berkenstein } \\
\text { Prezi }\end{array}$ \\
\hline $\begin{array}{l}\text { Deliverable: } \\
\text { Blog on contested } \\
\text { toponyms }\end{array}$ & $\begin{array}{l}\text { Week } 6- \\
\text { 1. Finish presentations } \\
\text { 2. Blogging with Wordpress (CPU lab) } \\
\text { 3. Contested Terrain/contested top- } \\
\text { onyms }\end{array}$ & $\begin{array}{l}\text { Articles on ICT and/or } \\
\text { blogs } \\
\text { Web 2.0- Wordpress }\end{array}$ \\
\hline $\begin{array}{l}\text { Unit } 3 \text { - Maps and } \\
\text { Storytelling } \\
\text { (Paper revisions due) } \\
\text { Deliverable: } \\
\text { Blog }\end{array}$ & $\begin{array}{l}\text { Week } 7- \\
\text { 1. PrairyErth discussion and negotiat- } \\
\text { ing the learning object: Deep maps } \\
\text { 2. Confirm constraints and group roles; } \\
\text { begin work } \\
\text { 3. Work session: Students are free to } \\
\text { conduct group work in class or else- } \\
\text { where (attendance is optional) }\end{array}$ & $\begin{array}{l}\text { PrairyErth by William } \\
\text { Least Heat-Moon } \\
\text { other Deep map ex- } \\
\text { amples }\end{array}$ \\
\hline & www.crossingtheborder.com.np & 73 \\
\hline
\end{tabular}




\section{Crossing the Border: International Journal of Interdisciplinary Studies}

\begin{tabular}{|c|c|c|}
\hline $\begin{array}{l}\text { Deliverables: } \\
\text { Deep map (collabora- } \\
\text { tive) } \\
\text { Blog }\end{array}$ & $\begin{array}{l}\text { Week } 8- \\
\text { 1. Intro to GoogleLitTrips/ Students } \\
\text { choose book } \\
\text { 2. Deep Map presentations } \\
\text { 3. Deep Map presentations }\end{array}$ & $\begin{array}{l}\text { GoogleEarth } \\
\text { Great American Novel } \\
\text { Map* } \\
\text { Prezi or Explain Every- } \\
\text { thing }\end{array}$ \\
\hline $\begin{array}{l}\text { Blog on Rory's Story } \\
\text { Cube revision }\end{array}$ & $\begin{array}{l}\text { Week } 9- \\
\text { 1. Storytelling: Revising Rory's Story } \\
\text { Cubes } \\
\text { 2. Review blogs/leave comments; Add } \\
\text { cube templates to Prezi (as a class) } \\
\text { 3. Storytelling: Introduction to the } \\
\text { PechaKucha\& negotiate the rules } \\
\text { and class theme }\end{array}$ & $\begin{array}{l}\text { Prezi } \\
\text { Wordpress } \\
\text { pechakucha.org } \\
\text { Powerpoint or similar }\end{array}$ \\
\hline $\begin{array}{l}\text { Unit } 4 \text { - Maps \& } \\
\text { Storytelling } \\
\text { Deliverable: } \\
\text { short presentation }\end{array}$ & $\begin{array}{l}\text { Week } 10- \\
\text { 1. Concept maps/discussion of the } \\
\text { books (groups) } \\
\text { 2. GoogleLitTrips progress reports } \\
\text { 3. GoogleLitTrips (CPU lab) }\end{array}$ & $\begin{array}{l}\text { Book by Your choice } \\
\text { Linoit }(1) \\
\text { GoogleEarth }(2 \& 3)\end{array}$ \\
\hline $\begin{array}{l}\text { Deliverable: } \\
\text { GoogleLitTrip } \\
\text { Blog }\end{array}$ & $\begin{array}{l}\text { Week } 11- \\
\text { 1. GoogleLitTrips Poster Presentations } \\
\text { 2. Introduction to Sophie \&ibook author } \\
\text { 3. Film - TBN }\end{array}$ & \\
\hline $\begin{array}{l}\text { Deliverable: } \\
\text { PechaKucha }\end{array}$ & $\begin{array}{l}\text { Week } 12- \\
\text { 1. Film - TBN } \\
\text { 2. PechaKucha presentations } \\
\text { 3. PechaKucha presentations }\end{array}$ & Powerpoint or similar \\
\hline $\begin{array}{l}\text { Unit } 5-\text { All the pretty } \\
\text { pictures }\end{array}$ & $\begin{array}{l}\text { Week } 13- \\
\text { 1. Deformative readings of the film } \\
\text { 2. Collaborative film theory: Co-con- } \\
\text { structing criteria for judging a film; } \\
\text { concept mapping activity } \\
\text { 3. outlining the review and begin work } \\
\text { on the blog (in-class) }\end{array}$ & $\begin{array}{l}\text { voyant-tools } \\
\text { other cloud tools } \\
\text { Linoit } \\
\text { students } \rightarrow \text { text students } \\
\text { bring to class their } \\
\text { favorite negative film } \\
\text { reviews } \\
\text { Wordpress (blog) }\end{array}$ \\
\hline $\begin{array}{l}\text { Deliverable: } \\
\text { Blog: Favorite deliver- } \\
\text { able }+2 \text { obstructions }\end{array}$ & $\begin{array}{l}\text { Week } 14- \\
\text { 1. } 5 \text { obstructions day- students present } \\
\text { their favorite deliverable thus far to } \\
\text { the class, peers advance obstruction } \\
\text { ideas } \\
\text { 2. Creating ebooks using ibookauthor } \\
\text { and Sophie } \\
\text { 3. ebook portfolio workshop }\end{array}$ & $\begin{array}{l}\text { Linoit } \\
\text { ibookauthor } \\
\text { Sophie }\end{array}$ \\
\hline $\begin{array}{l}\text { Deliverable: } \\
\text { Final } \\
\text { ebook portfolio } \\
\text { Final Exam: Online } \\
\text { - 1) Digital Literacy } \\
\text { \& Tools; 2) Style and } \\
\text { Citation }\end{array}$ & $\begin{array}{l}\text { Week } 15- \\
\text { 1. Scavenger hunt (based on deep map } \\
\text { projects) } \\
\text { 2. Presentation of final portfolio } \\
\text { 3. Presentation of final portfolio }\end{array}$ & $\begin{array}{l}\text { paper or digital - TBN } \\
\text { Prezi } \\
\text { Study Guide }\end{array}$ \\
\hline
\end{tabular}

* http://www.shortlist.com/entertainment/books/a-beautiful-great-american-novel-map TBN= To be negotiated 
TRANSFORM SPATIAL

\section{GRADING}

TBD

Required books:

Space and Place by Yi-Fu Tuan

In Praise of Shadows by Junichiro Tanizaki

PrairyErth by William Least Heat-Moon

All the Places to Love by Patricia McLachlan

\section{REFERENCES}

Arbib, M. A., Liebal, K., \& Pika, S. (2008). Primate vocalization, gesture, and the evolution of human language. Current Anthropology, 49(6), 1053-1076.

Arıc1, S., \& Aslan-Tutak, F. (2015). The effect of Origami-based instruction on spatial visualization, geometry achievement, and geometric reasoning. International Journal of Science and Mathematics Education, 13(1), 179-200.

Bach-y-Rita, P., Tyler, M. E., \& Kaczmarek, K. A. (2003). Seeing with the brain. International journal of human-computer interaction, 15(2), 285-295.

Bayrak, M. E. (2008). Investigation of effect of visual treatment on elementary school student's spatial ability and attitude toward spatial ability problems. Middle East Technical University.

Bednarz, R. S., \& Lee, J. (2011). The components of spatial thinking: empirical evidence. ProcediaSocial and Behavioral Sciences, 21, 103-107.

Bjork, O. (2013). Digital Humanities and the First-Year Writing Course. In B. Hirsch (Ed.), Digital Humanities Pedagogy: Practices, Principles and Politics (3 ed.): Open book.

Bodenhamer, D. J., Corrigan, J., \& Harris, T. M. (2010). The Spatial Humanities: GIS and the Future of Humanities Scholarship. Indiana University Press.

Boeree, C. (2000). Psychology: the beginnings. Retrieved from http://webspace.ship.edu/cgboer/ psychbeginnings.html

Bornstein, M. (2009). The mind of the preschool child: The intelligence-school interface. Handbookofearlychilddevelopmentandearlyeducation: Research to practice, 123-142.

Brunn, S. (2003). The New Worlds of Electronic Geography. Geotrópico, 1(1), 11-29. Retrieved from

Bush, P. (2015). Answer to Does the human brain work solely by pattern recognition? Retrieved from https://www.quora.com/Does-the-human-brain-work-solely-by-pattern-recognition

Çakmak, S. (2009). An investigation of the effect of origami-based instruction on elementary students'spatial ability in mathematics. Middle East Technical University.

Carroll, J. B. (1993). Human cognitive abilities: A survey of factor-analytic studies: Cambridge University Press.

Carruthers, P. (2002). The cognitive functions of language. Behavioral and Brain Sciences, 25(06), 657-674.

Casey, M. B., Nuttall, R. L., \& Pezaris, E. (1997). Mediators of gender differences in mathematics college entrance test scores: a comparison of spatial skills with internalized beliefs and anxieties. Developmental psychology, 33(4), 669.

Chinnery, H., \& Thompson Simon, B. (2015). Sensory Compensation in Children Following Vision Loss after Trauma and Disease. J Clin Res Ophthalmol 2 (4): 049, 53, 049.

Clark, A. (2008). Supersizing the mind: Embodiment, action, and cognitive extension: Oxford University Press.

Clark, J. M., \& Paivio, A. (1991). Dual coding theory and education. Educational psychology review, 3(3), 149-210.

Clements, D. H., \& Battista, M. T. (1992). Geometry and spatial reasoning.

Coleman, S. L., \& Gotch, A. J. (1998). Spatial perception skills of chemistry students. Journal of 


\section{Crossing the Border: International Journal of Interdisciplinary Studies}

Chemical Education, 75(2), 206.

Collignon, O., Voss, P., Lassonde, M., \& Lepore, F. (2009). Cross-modal plasticity for the spatial processing of sounds in visually deprived subjects. Experimental brain research, 192(3), 343-358.

Corrigan, J. (2015). Deep Maps and Spatial Narratives: Indiana University Press.

Council, N. R. (2006). Learning to think spatially. National Academies Press.

Cropley, A. (2006). In praise of convergent thinking. Creativity Research Journal, 18(3), 391-404.

Dehaene, S. (1997). The number sense. Oxford University Press. New York.

Dehaene, S., Spelke, E., Pinel, P., Stanescu, R., \& Tsivkin, S. (1999). Sources of mathematical thinking: Behavioral and brain-imaging evidence. Science, 284(5416), 970-974.

Dewey, J. (1990). The later works, 1925-1953. 17. 1885-1953:[miscellaneous writings]: Southern Ill. University Press.

Dictionaries, O. (2015). Oxford Dictionaries Word of the Year 2015 is... Retrieved from http://blog. oxforddictionaries.com/2015/11/word-of-the-year-2015-emoji/

Eliot, J., \& Smith, I. M. (1983). An international directory of spatial tests: Cengage Learning Emea.

Erkoç, M. F., Gecü, Z., \& Erkoç, Ç. (2013). The Effects of Using Google SketchUp on the Mental Rotation Skills of Eighth Grade Students*. Kuram ve Uygulamada Egitim Bilimleri, 13(2), 1285.

Friedman, L. (1995). The space factor in mathematics: Gender differences. Review of educational research, 65(1), 22-50.

Gaddis, J. L. (2002). The landscape of history: How historians map the past: Oxford University Press, USA.

Garcez, A. S. d. A., Broda, K., \& Gabbay, D. M. (2012). Neural-symbolic learning systems: foundations and applications: Springer Science \& Business Media.

Gardner, H. (1985). Frames of mind: The theory of multiple intelligences: Basic books.

Gersmehl, P. J., \& Gersmehl, C. A. (2007). Spatial thinking by young children: Neurologic evidence for early development and "educability". Journal of Geography, 106(5), 181-191.

Gilmartin, P. P., \& Patton, J. C. (1984). Comparing the sexes on spatial abilities: Map-use skills. Annals of the Association of American Geographers, 74(4), 605-619.

Golledge, R. G., Marsh, M., \& Battersby, S. (2008). Matching geospatial concepts with geographic educational needs. Geographical Research, 46(1), 85-98.

Golledge, R. G., \& Stimson, R. J. (1997). Spatial behavior: A geographic perspective: Guilford Press.

Goodchild, M. F., \& Janelle, D. G. (2010). Toward critical spatial thinking in the social sciences and humanities. GeoJournal, 75(1), 3-13.

Hannafin, R. D., Truxaw, M. P., Vermillion, J. R., \& Liu, Y. (2008). Effects of spatial ability and instructional program on geometry achievement. The Journal of Educational Research, 101(3), 148-157.

Hegarty, M., Crookes, R. D., Dara-Abrams, D., \& Shipley, T. F. (2010). Do all science disciplines rely on spatial abilities? Preliminary evidence from self-report questionnaires. Spatial Cognition VII (pp. 85-94): Springer.

Hermer-Vazquez, L., Spelke, E. S., \& Katsnelson, A. S. (1999). Sources of flexibility in human cognition: Dual-task studies of space and language. Cognitive psychology, 39(1), 3-36.

Humphreys, L. G., Lubinski, D., \& Yao, G. (1993). Utility of predicting group membership and the role of spatial visualization in becoming an engineer, physical scientist, or artist. Journal of Applied Psychology, 78(2), 250.

Hutton, J. S., Horowitz-Kraus, T., Mendelsohn, A. L., DeWitt, T., \& Holland, S. K. (2015). Home Reading Environment and Brain Activation in Preschool Children Listening to Stories. Pediatrics, 136(3), 466-478.

Janelle, D. G., \& Goodchild, M. F. (2009). Location across disciplines: reflections on the CSISS experience. Geospatial technology and the role of location in science (pp. 15-29): Springer.

John, Y. (2015). Answer to Does the human brain work solely by pattern recognition? Retrieved 
TRANSFORM SPATIAL

from https://www.quora.com/Does-the-human-brain-work-solely-by-pattern-recognition

Jones, A. (2010). Secondary school mathematics teachers' views of manipulatives and their use in the classroom. University of Ottawa.

Kahneman, D. (2011). Thinking, fast and slow: Macmillan.

Kaufman, D., \& Brooks, J. G. (1996). Interdisciplinary Collaboration in Teacher Education: A Constructivist Approach. TESOL Quarterly, 30(2), 231-251. doi:10.2307/3588142

Keehner, M. M., Tendick, F., Meng, M. V., Anwar, H. P., Hegarty, M., Stoller, M. L., \& Duh, Q.-Y. (2004). Spatial ability, experience, and skill in laparoscopic surgery. The American Journal of Surgery, 188(1), 71-75.

Kerski, J. J. (2003). The implementation and effectiveness of geographic information systems technology and methods in secondary education. Journal of Geography, 102(3), 128-137.

Kozhevnikov, M., Motes, M. A., \& Hegarty, M. (2007). Spatial visualization in physics problem solving. Cognitive science, 31(4), 549-579.

Lawson, B., \& Dorst, K. (2013). Design expertise: Routledge.

Lee, J., \& Bednarz, R. (2009). Effect of GIS learning on spatial thinking. Journal of Geography in Higher Education, 33(2), 183-198.

Linn, M. C., \& Petersen, A. C. (1985). Emergence and characterization of sex differences in spatial ability: A meta-analysis. Child development, 1479-1498.

Lohman, D. F. (1979). Spatial Ability: A Review and Reanalysis of the Correlational Literature.

McGrew, K. S. (2009). CHC theory and the human cognitive abilities project: Standing on the shoulders of the giants of psychometric intelligence research. Intelligence, 37(1), 1-10.

Montello, D. R., Lovelace, K. L., Golledge, R. G., \& Self, C. M. (1999). Sex-related differences and similarities in geographic and environmental spatial abilities. Annals of the Association of American Geographers, 89(3), 515-534.

Morris, P. (2009). The Bakhtin Reader: Selected Writings of Bakhtin, Medvedev, Voloshinov: Bloomsbury Academic.

Mulhere, K. (2015). Seeing in New Dimensions. Inside Higher Ed. Retrieved from https://www. insidehighered.com/news/2015/03/17/comic-book-dissertation-demonstrates-capacity-picturewriting

NCTE. (2005). Position Statement on Multimodal Literacies. Retrieved from http://www.ncte.org/ positions/statements/multimodalliteracies

Newcombe, N., Epstein, R., \& Shipley, T. (2015). Initiative 1: Characterize spatial skills relevant to STEM and chart their development. Retrieved from http://spatiallearning.org/index.php/initiatives/initiative-1-characterize-skills

Newcombe, N. S., \& Frick, A. (2010). Early education for spatial intelligence: Why, what, and how. Mind, Brain, and Education, 4(3), 102-111.

Orion, N., Ben-Chaim, D., \& Kali, Y. (1997). Relationship between earth-science education and spatial visualization. Journal of Geoscience Education, 45, 129-132.

Ortega, S., \& Stewart, K. (2014). Committee on Educaitonal Planning, Policies, and Program.

P21. (2011). Framework for 21st century learning. Retrieved from http://www.p21.org/storage/documents/1._p21_framework_2-pager.pdf

Paivio, A. (1983). The empirical case for dual coding. Imagery, memory and cognition, 307-332.

Paivio, A. (2010). Dual coding theory and the mental lexicon. The Mental Lexicon, 5(2), 205-230.

Peters, M., Chisholm, P., \& Laeng, B. (1995). Spatial ability, student gender, and academic performance. Journal of Engineering Education, 84(1), 69-73.

Peterson, K. D., Jr. (2000). Using a Geographic Information System to Teach Economics. The Journal of Economic Education, 31(2), 169-178. doi:10.2307/1183188

Piaget, J., Cook, M., \& Norton, W. (1952). The origins of intelligence in children (Vol. 8): International Universities Press New York.

www.crossingtheborder.com.np 


\section{Crossing the Border: International Journal of Interdisciplinary Studies}

Piaget, J., \& Inhelder, B. (1948). La représentation de l'espace chez l'enfant.

Rohde, T. E., \& Thompson, L. A. (2007). Predicting academic achievement with cognitive ability. Intelligence, 35(1), 83-92.

Sadoski, M., \& Paivio, A. (2001). Imagery and text: A dual coding theory of reading and writing.

Sawyer, R. K. (2014). The Cambridge handbook of the learning sciences (2nd ed.): Cambridge University Press.

Sawyer, R. K. (2015). The origin of "creativity". Retrieved from https://keithsawyer.wordpress. com/2015/10/01/the-origin-of-creativity/

Schneider, W., \& McGrew, K. (2012). The Cattell-Horn-Carroll model of intelligence. Contemporary intellectual assessment: Theories, tests, and(3rd), 99-144.

Schueneman, A. L., Pickleman, J., Hesslein, R., \& Freeark, R. (1984). Neuropsychologic predictors of operative skill among general surgery residents. Surgery, 96(2), 288-295.

Schwartz, D. L., \& Black, J. B. (1996). Shuttling between depictive models and abstract rules: Induction and fallback. Cognitive science, 20(4), 457-497.

Sorby, S. A. (2001). A course in spatial visualization and its impact on the retention of female engineering students. Journal of women and minorities in science and engineering, 7(2).

Stevick, E. W. (1986). Images and options in the language classroom: Cambridge University Press.

Stieff, M. (2007). Mental rotation and diagrammatic reasoning in science. Learning and instruction, 17(2), 219-234.

Sui, D. Z. (2004). GIS, Cartography, and the "Third Culture": Geographic Imaginations in the Computer Age*. The Professional Geographer, 56(1), 62-72.

Sun, R., \& Alexandre, F. (2013). Connectionist-symbolic integration: From unified to hybrid approaches: Psychology Press.

TeachSpatial. (2015). Spatial concepts in U.S. science teaching standards. Retrieved from http://www. teachspatial.org/standards-browser

Travis, C. (2015a). Abstract Machine: Humanities GIS.

Travis, C. (2015b). Visual Geo-Literary and Historical Analysis, Tweetflickrtubing, and James Joyce's Ulysses (1922). Annals of the Association of American Geographers, 105(5), 927-950.

Voss, P., Lassonde, M., Gougoux, F., Fortin, M., Guillemot, J.-P., \& Lepore, F. (2004). Early-and late-onset blind individuals show supra-normal auditory abilities in far-space. Current Biology, 14(19), 1734-1738.

Vygotsky, L. S. (1978). Mind in society: The development of higher psychological processes: Harvard university press.

Wai, J., Lubinski, D., \& Benbow, C. P. (2009). Spatial ability for STEM domains: aligning over 50 years of cumulative psychological knowledge solidifies its importance. Journal of Educational Psychology, 101(4), 817.

Waterhouse, L. (2006). Multiple intelligences, the Mozart effect, and emotional intelligence: A critical review. Educational Psychologist, 41(4), 207-225.

Wright, R., Thompson, W. L., Ganis, G., Newcombe, N. S., \& Kosslyn, S. M. (2008). Training generalized spatial skills. Psychonomic Bulletin \& Review, 15(4), 763-771.

\section{ABOUT THE AUTHOR}

Alex Lowry is a doctoral student in Curriculum \& Instruction at the University of North Carolina at Chapel Hill, and the 2015-2016 English Language Fellow to Nepal. He currently lives in Pokhara, Nepal, and co-teaches several courses in the Department of English Education at Prithvi Narayan Campus of Tribhuvan University with his Nepalese counterparts. His research interests include dual coding theory, second language acquisition (SLA), spatial pedagogy, extended cognition, socio-cultural theories of learning, and culturally relevant pedagogy. 